\title{
Poverty and Growth in the WAEMU after the 1994 Devaluation
}

\author{
Jean-Paul Azam*
}

February 2004

\begin{abstract}
This paper brings out that poverty increased massively in the wake of the 1994 devaluation of the CFA franc, despite a significant recovery of economic growth. Although this increase affected all the social groups, it fell mostly on the urban poor. An analytical model is presented, which explains this puzzle by the stratification of the labour market, assuming that the formal sector workers are at the same time the investors in the informal sector. Then, capital intensity in the latter increases as the former anticipate the cut in formal sector wages that the long-awaited devaluation brings about. Ex post, they run down their assets for consumption-smoothing purposes, thus de-capitalizing the informal sector firms, with a negative impact on incomes in the (urban) informal sector.
\end{abstract}

Keywords: Côte d'Ivoire, Niger, poverty, exchange rate

JEL classification: D31, O11

\section{Copyright @ C UNU-WIDER 2004}

* University of Toulouse and Institut Universitaire de France, ARQADE, IDEI, and CSAE, Oxford.

This study has been prepared within the UNU-WIDER project on 'Long-Term Development in the CFAzone Countries of Sub-Saharan Africa’, directed by David Fielding.

UNU-WIDER gratefully acknowledges the financial contribution to the project by the Finnish Ministry for Foreign Affairs.

UNU-WIDER also acknowledges the financial contributions to the research programme by the governments of Denmark (Royal Ministry of Foreign Affairs), Norway (Royal Ministry of Foreign Affairs), Sweden (Swedish International Development Cooperation Agency - Sida) and the United Kingdom (Department for International Development). 


\section{Acknowledgements}

This paper was presented at the UNU-WIDER Project Meeting: Long-Term Development in the CFA-Zone Countries of Sub-Saharan Africa, 27-28 June 2003, Helsinki, Finland. Useful comments by Lambert Bamba N'Galadjo, Jean-Claude Berthélemy, David Fielding, Moubarack Lo and Anja Shortland are gratefully acknowledged. This paper uses some statistical results initially presented in 'The 1994 Devaluation and Poverty in the WAEMU' (with Waly Wane), unpublished, World Bank: Washington, DC, 2001. It has benefited from comments by Lionel Demery, and by participants at an IDS/World Bank meeting in Brighton, UK in April 1999. The interpretation of these results, and the analytical model that supports it, are new. The views expressed are those of the author, and do not necessarily represent those of the World Bank. Special thanks are due to Idrissa Ouattara, without implicating.

The World Institute for Development Economics Research (WIDER) was established by the United Nations University (UNU) as its first research and training centre and started work in Helsinki, Finland in 1985. The Institute undertakes applied research and policy analysis on structural changes affecting the developing and transitional economies, provides a forum for the advocacy of policies leading to robust, equitable and environmentally sustainable growth, and promotes capacity strengthening and training in the field of economic and social policy making. Work is carried out by staff researchers and visiting scholars in Helsinki and through networks of collaborating scholars and institutions around the world.

www.wider.unu.edu

publications@wider.unu.edu

UNU World Institute for Development Economics Research (UNU-WIDER)

Katajanokanlaituri 6 B, 00160 Helsinki, Finland

Camera-ready typescript prepared by Janis Vehmaan-Kreula at UNU-WIDER

Printed at UNU-WIDER, Helsinki

The views expressed in this publication are those of the author(s). Publication does not imply endorsement by the Institute or the United Nations University, nor by the programme/project sponsors, of any of the views expressed. 
The decision to devalue the CFAF in January 1994 has probably been one of the longest awaited decisions in the modern history of adjustment policies. The exchange rate with the French franc had not changed since 1948. While the performance of the CFA zone economies were much better than those of the other African economies until the collapse of most commodity prices in 1986-88, the latter have been undoubtedly much better at adjusting to these shocks (Devarajan and Rodrik 1992). Probably, it was in 1989 that the need to devalue was the most acute, after the collapse of the terms of trade in most of the zone at the end of 1987, and the decision by president Houphouët-Boigny of Côte d'Ivoire to withdraw the whole cocoa crop from the market in 1988. He was trying to support single-handedly the world cocoa market, and this ruined his country's creditworthiness (Azam and Morrisson 1994). The impact of this worsening of the macroeconomic situation on poverty, in the wake of the terms-of-trade collapse, can only be analysed in the case of Côte d'Ivoire, among the CFA zone countries, as none of the other ones has two household surveys performed at the relevant dates, to compare the outcomes before and after this shock. Figure 1, derived from Demery and Squire (1996) shows that Côte d'Ivoire saw its poverty level increase as macroeconomic policy was deteriorating, over the 1985-88 period, contrary to the countries presented for comparison. In fact, the deterioration mainly occurred during the last year of this period. Not everybody suffered equally in this country from the downturn, which had a positive distributional effect on some groups (Grootaert and Kanbur 1995). In particular, as explained below in section 3, poverty decreased over that period in the urban informal sector, especially before the terms-of-trade crash which occurred at the end of 1987 (Grootaert 1996).

Probably, it would be mistaken to take Côte d'Ivoire as representative of the whole CFA zone, although it is the leading economy of this area. It fared especially badly after 1986, as its terms of trade deteriorated catastrophically, while some unwelcome policy decisions were taken. Nevertheless, the existing analyses of the evolution of poverty over that period of deteriorating macroeconomic policies provides some clues about the relevant phenomena to look at when observing the impact of policy changes on poverty (Grootaert and Kanbur 1995, Grootaert 1996). They show the diversity of the impact on different groups of households, depending on the regions where they live, their occupation, and their socio-economic status. For example, Grootaert and Kanbur (1995) show that households from the east forest area had a 20.4 per cent probability of improving their poverty status despite the worsening macroeconomic situation in 198788, while the food crop farmers had a 39.1 per cent probability of doing so over the same period. Hence, one might expect to meet similarly diverse effects in response to the improved macroeconomic situation that resulted from the devaluation and the accompanying measures. In fact, a much simpler picture emerges from the results presented below.

Nevertheless, despite the widespread increase in poverty in 1987-88, in the wake of the terms of trade crash, it was not until Houphouët's death, in December 1993, that the decision to devalue was obtained by Michel Camdessus, on behalf of the IMF, in January 1994. The theory of postponed policy reforms, developed in particular by Alesina and Drazen (1991), Fernandez and Rodrik (1991) and Casella and Eichengreen (1996), points to the uncertainty of the distributional impacts of the reforms as the main cause of delay. The results presented below, which are somehow unexpected, might 
Figure 1

Poverty and macroeconomic policy

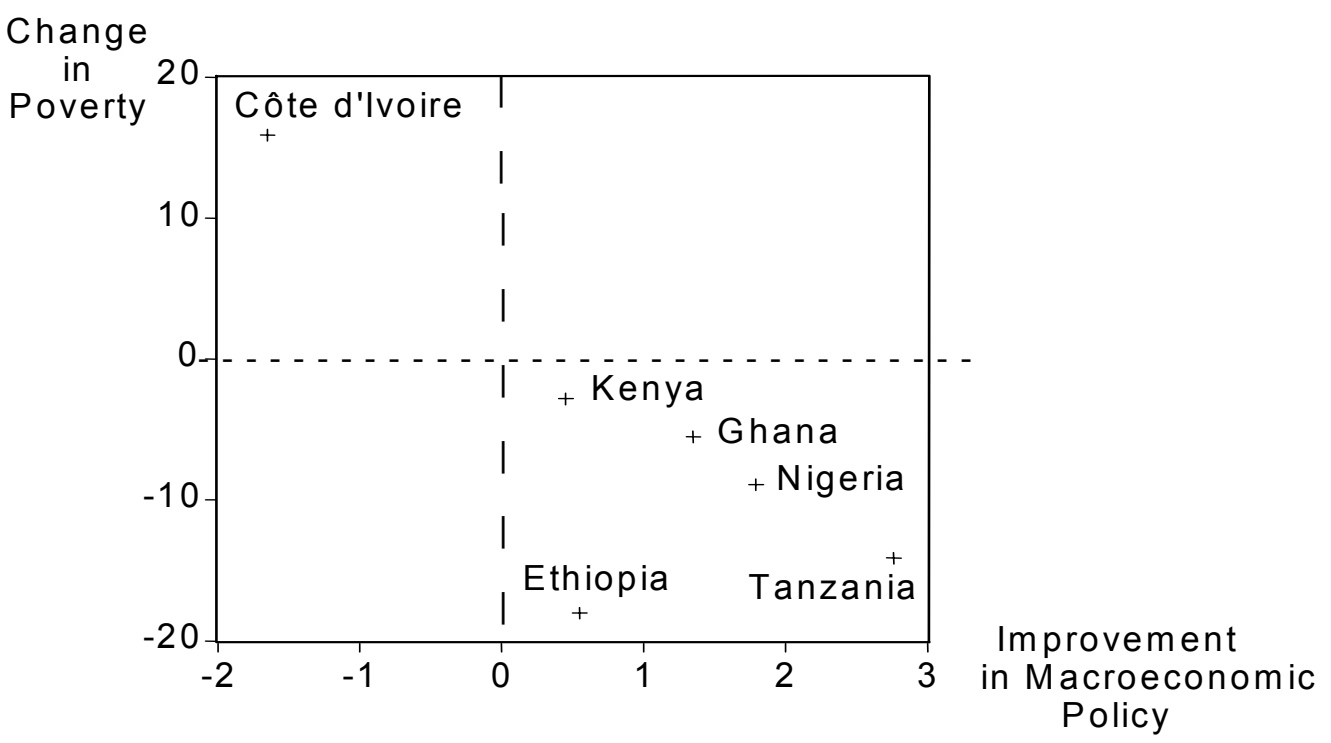

Source: Derived from Demery and Squire (1996).

provide some support to this view (see also Azam 1994). In fact, it turns out that the observed growth recovery left many people aside, as poverty increased.

In the case of the CFA zone economies, the fixed exchange rate with the French Franc, which has been de facto linked to the DM since 1983, together with the swings in the US\$ and in the prices of their main export commodities, had resulted in excessively high wages in the formal sector, widely recognized as such (see Van de Walle 1991). Hence, the fixed exchange rate was then protecting 'The Lucky Few Amidst Economic Decline' (Grootaert and Kanbur 1995). Therefore, many felt that the only remaining uncertainty was concerning the ability of the wage earners from the formal sector to pass on any devaluation to wage increases, thus triggering an inflationary wage-price spiral mediated by repeated devaluation. The French were wary about this, and supported until the fall of 1993 the resolve of most CFA countries rulers not to devalue, fearing probably a contagion effect onto the French franc. This did not happen, although the 1994 devaluation took place in an electoral context. Wages in the formal sector did not respond much, as shown below, and this explains the success of this policy reform, from a macroeconomic point of view.

The next section briefly presents the main impact of the devaluation on growth and inflation, focusing on the WAEMU (West African Economic and Monetary Union) countries. The oil-rich CEMAC countries probably require a different analysis. Growth resumed, while inflation fell short of catching up on the devaluation, leaving a high degree of effectiveness. Section 3 looks at the net effect of the devaluation package on poverty in the cases of Côte d'Ivoire and Niger, where the availability of two household surveys, before and after the devaluation, allows for some tracking of the change in poverty. Other surveys have been performed since then in other countries, mainly in the 
early 2000 s, that is, too long after the devaluation to be really useful for the purpose at hand. The focus is put on the changes affecting the different occupational categories, which are likely to represent accurately the different segments of the labour market. A simple model is presented in section 4 to provide a theoretical framework for thinking about the way in which a cut in real formal sector wages works through the various segments of the labour market to affect the incomes of the workers in the informal sector, where most of the poor earn their living. This model is a simple dynamic analysis, which takes on board the widely observed fact that formal sector workers are generally running businesses in the informal sector, where they often hire workers from their social network (kin group, village of origin, extended family, etc.). The relevance of this approach is supported by reference to some results which surprised the donor community in the late 1980 s, and which square very well with the explanation presented here (Azam et al. 1993, Grootaert 1996).

\section{The recovery of economic growth after the devaluation}

The overvaluation of the CFAF was taking its toll on the economies of the CFA zone before the 1994 devaluation, as can be seen by looking at their growth performance. The three panels of figure 2 show that the most affected economy was Côte d'Ivoire, which experienced negative growth since 1987, when its terms of trade started on a steep downward slide until 1992. Most of these economies experienced some negative growth in the early 1990s, most of them in 1993, and sometimes before, like Niger and Togo. Benin seems to have been unaffected by this phenomenon. Two main events explain the bad performance experienced in 1993 in the WAEMU. First, Côte d'Ivoire was put under sanction by the International Financial Institutions, who wanted to induce its president to accept the devaluation, and the resulting lack of any external funding for supporting effective demand decimated its industrial sector; second, in August 1993, under the pressure of the French treasury, the BCEAO (the central bank of the WAEMU), suspended the external convertibility of the CFA bank notes (see Azam 1997). The cost of the resulting speculative attack, which was easily predictable from elementary open-economy macroeconomics, has been estimated at US\$ 610 million of foreign exchange reserves. A further credit squeeze followed and made the slump more damaging. Part of the benefit of the devaluation resulted from the lifting of sanctions and from the massive loans that the countries got from outside. The IMF and the World Bank started new programmes with these governments, which relieved the self-inflicted foreign exchange shortage. With the exception of Benin, which went through 1993 without apparent trouble, growth recovered in all these countries after the devaluation, and became smoother. With the exception of Benin and Senegal, all these countries saw the post devaluation boom slow down in the year 2000, with Côte d'Ivoire, Niger and Togo going into recession. 
Figure 2a

Real GDP in Côte d'Ivoire and Senegal (log scale)

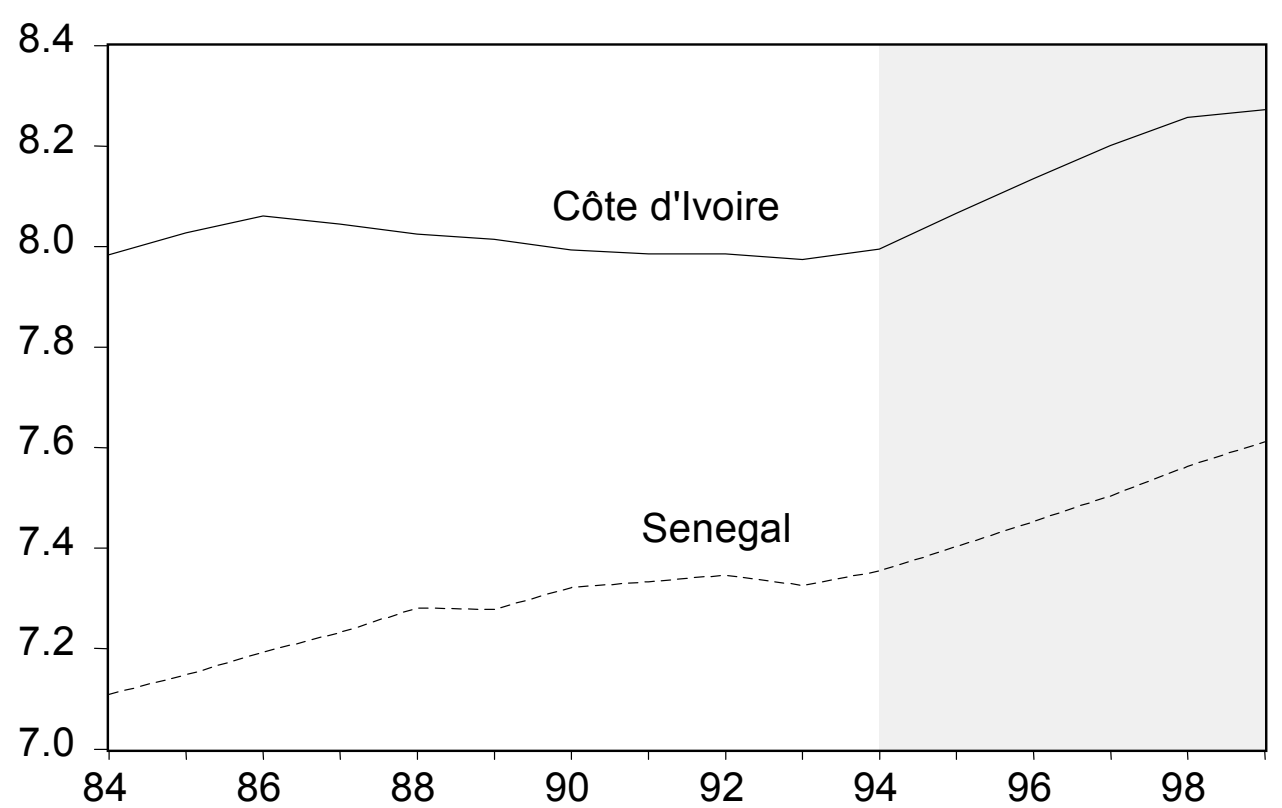

Figure $2 b$

Real GDP in Burkina Faso, Mali and Niger (log scale)

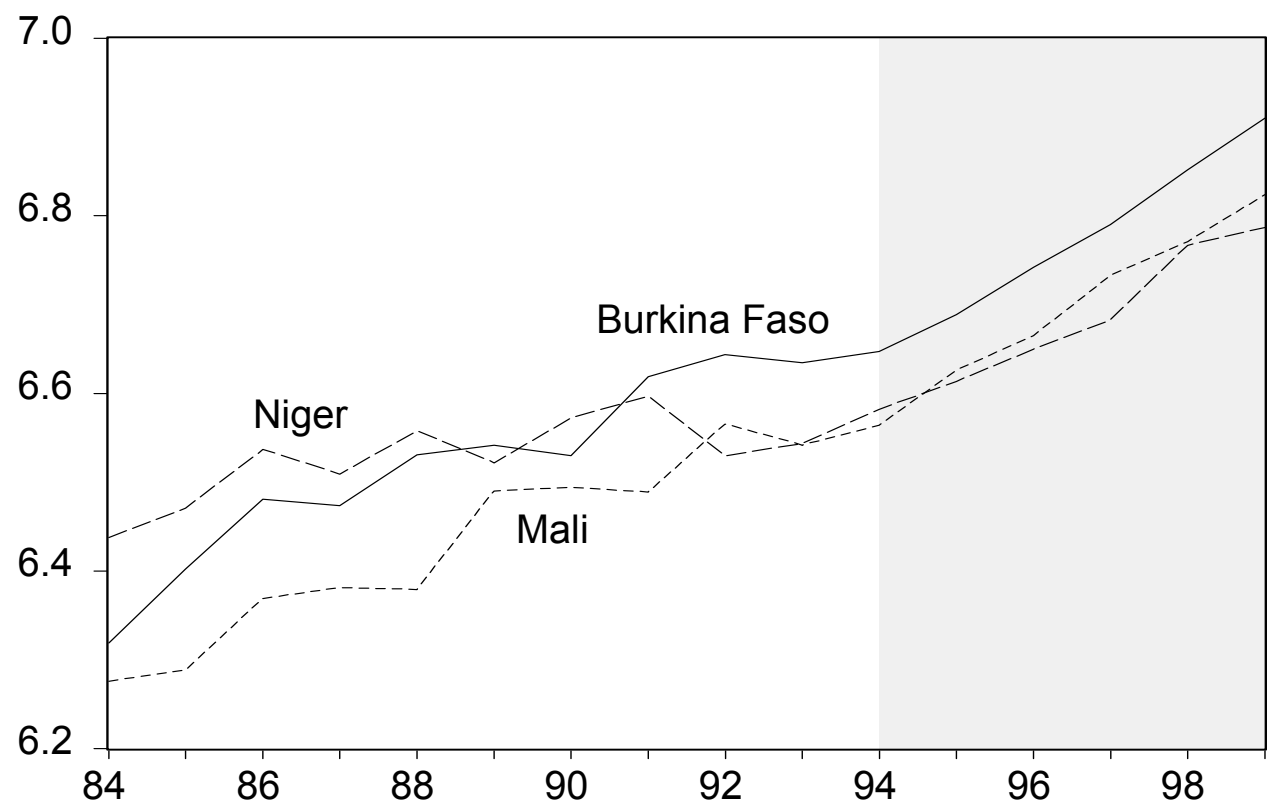


Figure 2c

Real GDP in Benin and Togo (log scale)

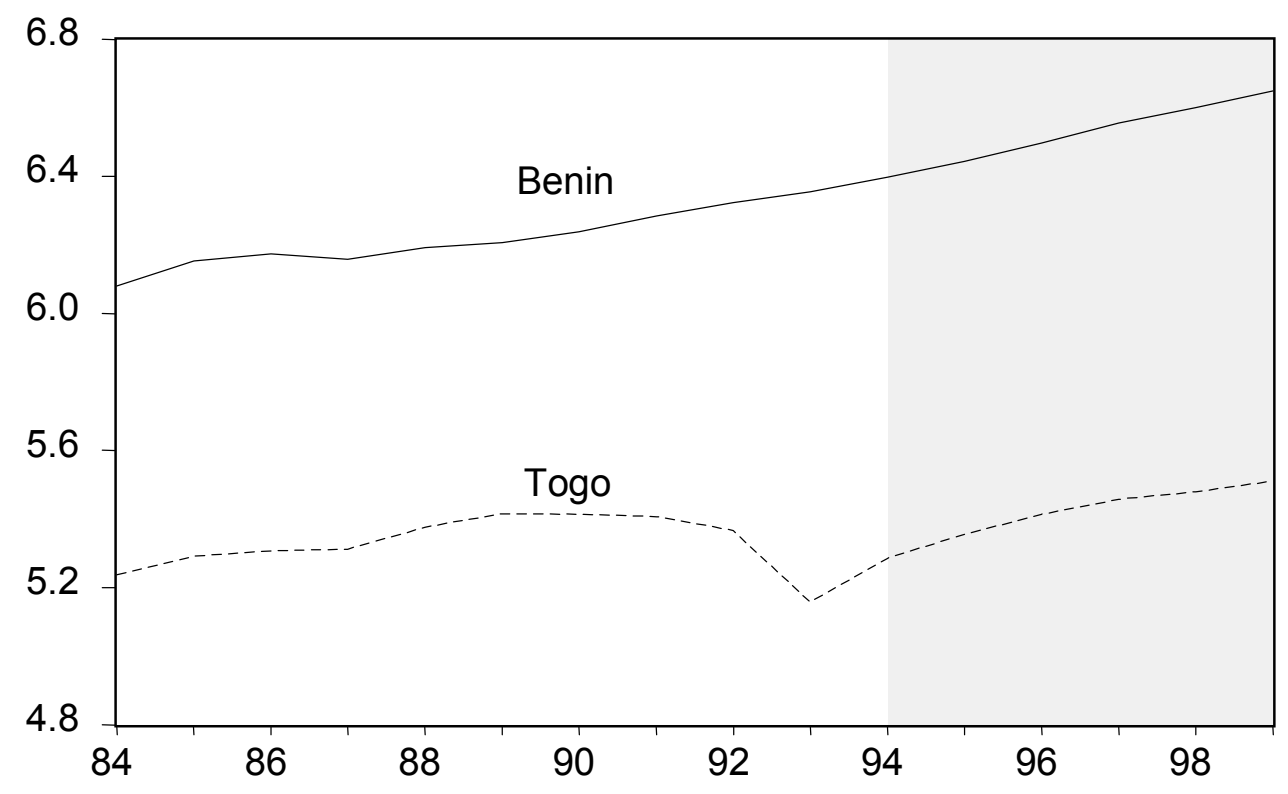

The WAEMU countries have traditionally very low rates of inflation, for two reasons. First, this is due in part to the fixed exchange rate with France, which translates into a fixed exchange rate with low-inflation Germany since 1983. Second, it is also due, for some of these countries, to the fact that their consumer goods markets are largely integrated with Nigeria, through unrecorded cross-border trade, so that the fast depreciation of the naira on the parallel market entails some price deflation in some of its CFA neighbours (see Azam 1991). This is especially true of Niger. Although some of the 100 per cent devaluation was passed on to consumer prices in 1994 and the subsequent years, its effectiveness has been quite high. Between 1994 and 1996, the cumulative rate of inflation ranges between 35.6 per cent in Burkina Faso, and 48.5 per cent in Benin. By 1999, this range is between 36.3 per cent in Burkina Faso and 52.6 per cent in Benin. Despite this high degree of effectiveness, the 1994 devaluation did not affect much relative consumer prices, as shown econometrically by Azam and Wane (2001). Using some dis-aggregated consumer price indices for Côte d'Ivoire, Niger and Senegal, they have tested for a significant change in the structure of relative prices by running some regressions on monthly prices. Only second-order effects can be identified in these consumer price series. They conclude that this cannot be the main effect of the devaluation, as no significant impact is found, for most goods. In particular, these results undermine the relevance of the view that the main role of devaluation is to affect the relative price of tradable and non tradable goods, suggesting that this variable has been largely over-emphasized in policy debates about Francophone Africa. 
Figure 3

Relation between public wages and public employment (1987)

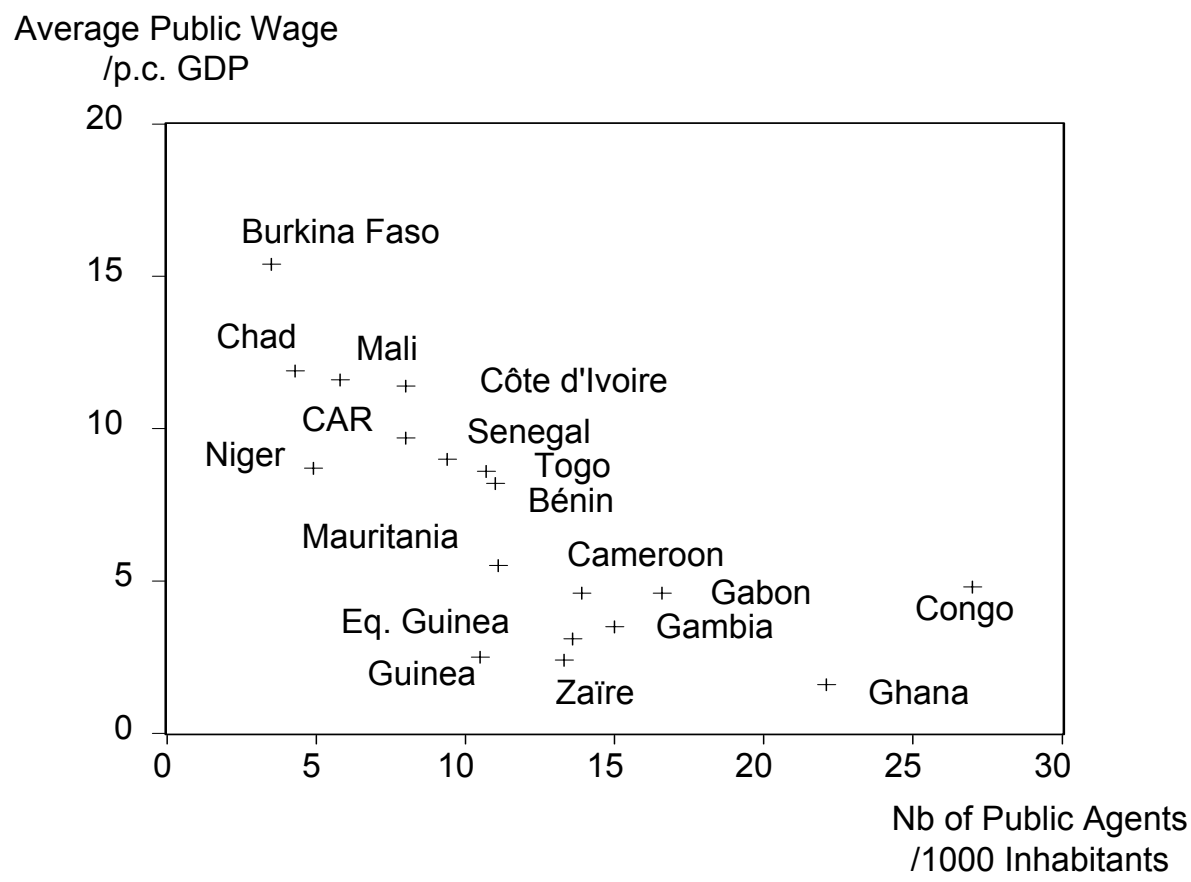

Source: Azam (1995).

Figure 3 illustrates the main problem that was facing the CFA zone before the devaluation: the too high wages in the public sector (see Van de Walle 1991, and Rama 2000). In this plot, the ratio of the wage rate in the public sector to per capita GDP is on the $y$-axis, while the number of public agents per 1000 inhabitants is on the $x$-axis. The chart shows that the WAEMU countries were massively located in the north-western quarter of this space, where the average public sector wage is more than eight times larger than per capita GDP, and more than ten times so for Burkina Faso, Mali and Côte d'Ivoire. By contrast, the supply of public services, as measured by the number of public agents, was below standards. Chad and the Central African Republic, the non-oil exporting members of the CEMAC (Central African Economic and Monetary Community) were also located in the same part of the chart. This chart also suggests that wage rigidity was lying at the heart of the problem, because in the lower half of this space, one finds either oil economies, where the denominator is inflated by oil revenues, or countries with a flexible exchange rate, and a history of more or less rapid depreciation, that kept a check on the real wage cost of public sector employees. The non-oil fixed-rates countries all suffered from excessive public sector wages, relative to the others.

Rama (2000) has analysed wage misalignment in the CFA countries, and concludes that real wage rigidity is involved in the long run, and not the type of nominal wage rigidity that makes devaluation work. However, the post-devaluation record shows that the catching-up of public sector wages on the price level is very slow indeed. This might be due to a structural break in the real wage series, as public sector workers had long relied 
on France to prevent the devaluation of the CFAF and the fall in their real wages. In this interpretation, the 1994 decision came as a revelation that the former colonial power would not anymore stand ready to finance any public sector deficit, and therefore would not support the purchasing power of the civil servants forever. However, wages and salaries had been cut already in some countries, like Cameroon and Senegal, and frozen in others, so that civil servants and formal sector wage earners were most probably expecting that a downward adjustment of their earnings would come sooner or later, one way or another.

In any case, wage moderation in the public sector has been remarkable after the devaluation, while several electoral episodes had led some to fear some wage explosion. In particular, the 1995 elections in Côte d'Ivoire have given rise to no wage increases, and this stability has remained in place until the military coup of 24 December 1999, which gave rise to a large increase in the wages of military personnel. The level of public sector wages does not matter only from a budgetary point of view, as Rama (2000) has shown that it affects in fact the level of wages in the whole formal sector of the economy, by contagion. As productivity is much higher there than in the other sectors, the real cost of labour in this sector has important macroeconomic effects, insofar as it affects negatively employment and output in this sector.

In Côte d'Ivoire, the hourly minimum wage rate had been CFAF 191.4 between January 1982 and February 1994, when it was increased to 212, its current value (IMF 2000a). In Senegal, it has been 174.9 between April 1983 and January 1985, when it became 183.8, until July 1989, when it reached 201.1. It was then increased to 209 in December 1996, and to 209.1 in December 1997 (IMF 2000b). However, Rama's results suggest that we should not pay too much attention to this minimum wage, which does not seem to affect the wages actually paid in any sector (Rama 2000). More significant is the annual rate of change of the average wage in the central government, presented in table 1 , for the two leading economies of the WAEMU, namely Côte d'Ivoire and Senegal. It shows that wage increases have been extremely moderate in the civil service, at an annual rate below 4.6 per cent on average in Côte d'Ivoire, and below 0.8 per cent on average in Senegal, mainly because of the fall preceding the devaluation. This provides the basic stylized fact of the impact of the 1994 devaluation on the WAEMU economies: it engineered a sizeable cut in the real wages in the civil service, and most probably also in the whole public sector, and by contagion, in the whole formal sector. At the same time, some downsizing of the staff of the central government, by 5.1 per cent in 1994 and 1.9 per cent in 1995 occurred in Côte d'Ivoire, while this was negligible in Senegal.

Table 1

Annual rate of change of the average wage in central government (\%)

\begin{tabular}{cccccccc}
\hline Year & 1993 & 1994 & 1995 & 1996 & 1997 & 1998 & 1999 \\
\hline Côte d'Ivoire & na & 7.4 & 3.7 & 0.0 & 1.5 & 10.2 & 4.5 \\
Senegal & -7.2 & 12 & -5.3 & 3.2 & -1.8 & 0.7 & 3.6 \\
\hline
\end{tabular}

Source: IMF (2000a) and (2000b).

This fall in the real wages in the formal sector contributed certainly to the resumption of GDP growth both by restoring the fiscal situation, allowing public investment to recover, and by restoring the profits of the modern sector firms, boosting their incentive 
to invest and expand their activity. This explains the growth recovery seen above, which was fuelled by this boost of the competitiveness and profitability of the formal sector firms. However, this leaves the increase in poverty that took place at the same time unexplained. The latter is presented in detail in the next section.

\section{Deepening poverty in Côte d'Ivoire (1993-95) and Niger (1994-95)}

In this section, some results are presented on the decomposition of poverty among different socio-economic groups in Côte d'Ivoire and Niger, from Azam and Wane (2001). These two countries have performed household surveys at two successive dates about 1994, that can help shed some light on the short-run impact of the devaluation on poverty. It should be emphasized that the resulting sample is not a panel, so that a transition analysis as performed by Grootaert and Kanbur (1995) is not possible. It is thus impossible to disentangle in the observed change in the distribution of income, as measured by consumption expenditures, what is due to the impact of the devaluation from what is due to a sampling problem, such that this distribution would be different even if the devaluation had not taken place. This remark is especially relevant for Côte d'Ivoire, whose two samples are different in obvious ways, as described below. Therefore, it is important to check the validity of our results by going beyond the global figures, and look at the 'before-after' changes using different decompositions of the samples, in order to check that the results seem robust in this respect. However, this does not seem to be so relevant for Niger.

Only the Côte d'Ivoire surveys are really suitable for this exercise, as one took place just before the devaluation, in 1993, followed by a second one in 1995, after a full year in the post-devaluation era. However, even this pair of surveys raises problems, which have always stood in the way of a fully satisfactory analysis of poverty in this country, despite its large number of household surveys. As emphasized by Grootaert and Kanbur (1995) and by Grootaert (1996), this country has long had a deficient price index. The consumer price index collected by the statistical office has long been restricted to Abidjan, and it is only recently that a more comprehensive price index, covering some information about the countryside, has been collected. It became operational for the analysis of the 1998 household survey (see Kouadio et al. 2000). Here, the deflator used comes from the World Bank's tables (World Bank 1997), from which an inflation of 44 per cent can be computed, over the two years. It is probably an overestimate, as prices might possibly have increased more slowly outside Abidjan. The 1993 survey was a socalled priority survey on the social dimensions of adjustment, and interviewed a total of 10080 households. In fact 1,680 households from Abidjan were actually surveyed in 1992, and another 480 in 1993, while all the other households were surveyed in 1993 (see Ouattara 1997). The 1995 survey was a living standards survey, with a more complete questionnaire, but a much smaller sample. Only 1,200 households were surveyed in this round, 1,000 picked fully at random, and 200 among the households surveyed in 1993. This drastic difference in sample size between the two dates may legitimately raise some suspicion about how representative is the second one. This problem does not arise with the surveys of Niger.

Table 2 presents the contributions of different groups to poverty, using the Foster, Greer and Thorbecke (1984) measure. These computations are done with respect to the poverty line $z=144,800$ CFAF suggested by the World Bank, for Côte d'Ivoire. Three 
measures of poverty are presented: the Head Count ratio $\left(P_{0}\right)$, the Poverty Gap $\left(P_{1}\right)$ and the FGT2 $\left(P_{2}\right)$. They are all derived from the so-called FGT family (Foster, Greer and Thorbeke 1984). Its general formula is:

$$
P_{\alpha}=\frac{1}{n} \sum_{i \leq q}\left(\frac{z-y_{i}}{z}\right)^{\alpha}
$$

where $z$ is the poverty line, $y_{i}$ is individual $i$ 's income, usually measured by consumption. The individuals are assumed to be ranked from the poorest to the richest, with $i$ running from 1 to $n$, and $q$ being the index of the individual whose income is just at the poverty line. This poverty measure has two attractive characteristics, that explain its widespread use. First, it is decomposable, in that it can be computed for different sub-groups of the population, without changing the total. Second, it encompasses several widely used measures, depending on the value chosen for $\alpha$. When $\alpha=0$, it is in fact the headcount ratio $q / n$, that is, the ratio of the number of poor to the total population. When $\alpha=1$, we find the headcount ratio multiplied by the average income gap, that is, the average distance of the incomes in the group of the poor to the poverty line, which can be written as follows, defining $\bar{y}$ as the average income of this group:

$$
P_{1}=\frac{q}{n} \frac{z-\bar{y}}{z}
$$

Both of these versions of the FGT measure treat equally all the persons below the poverty line. The headcount ratio is the most widely used index, but it does not take into account the depth of poverty. The weighted poverty gap $P_{l}$ does this, but does not take into account the inequality among the poor, which it treats equally. For example, a mean-preserving spread of the income distribution among the poor, with some of them coming closer to the poverty line, while others would move into deeper poverty, would not affect it. Hence, some authors prefer to choose $\alpha=2$, which amounts to weighting each person's poverty gap by itself, thus giving more weight to the poorest of the poor. Table 2 shows the values of these three measures for Côte d'Ivoire, computed from the 1993 and the 1995 surveys, according to different partitions of the population.

The first partition aims at bringing out the different impact on different occupations. It shows that poverty increased in all the occupational categories, whichever measure is used. In relative terms, it is undoubtedly the skilled employees, a typical formal sector category, who got the hardest blow. The second partition presented looks at the impact by industry. Here again, poverty goes up, according to all the measures. However, it is clear that poverty went up more strongly among the public sector workers, and in the commerce sector. Transportation was more or less unaffected. The sector labelled 'secondary' involves manufacturing industry and mining, and displays also a deterioration of the poverty situation. 
Table 2

Côte d'Ivoire: Contribution to poverty of different groups before and after the devaluation (\%)

\begin{tabular}{|c|c|c|c|c|c|c|}
\hline & \multicolumn{6}{|c|}{ Poverty line $z=$ CFAF 144800} \\
\hline & \multicolumn{2}{|c|}{ Head count $P_{0}$} & \multicolumn{2}{|c|}{ Poverty gap $P_{1}$} & \multicolumn{2}{|c|}{ FGT $P_{2}$} \\
\hline & 1993 & 1995 & 1993 & 1995 & 1993 & 1995 \\
\hline \multicolumn{7}{|l|}{ Socio-economic category } \\
\hline Unknown & 44.5 & 55.4 & 1.73 & 2.96 & 0.105 & 0.252 \\
\hline Self employed & 65.4 & 75.8 & 3.23 & 5.04 & 0.237 & 0.472 \\
\hline Unskilled employee & 40.9 & 57.0 & 1.57 & 2.51 & 0.100 & 0.167 \\
\hline Traders & 38.1 & 57.4 & 1.43 & 2.74 & 0.086 & 0.186 \\
\hline Skilled employees & 17.6 & 36.1 & 0.498 & 1.40 & 0.025 & 0.085 \\
\hline Others & 36.1 & 52.5 & 1.56 & 2.69 & 0.108 & 0.203 \\
\hline \multicolumn{7}{|l|}{ Sector of activity } \\
\hline Unknown & 44.5 & 55.4 & 1.73 & 2.96 & 0.105 & 0.253 \\
\hline Primary & 70.3 & 76.3 & 3.58 & 5.17 & 0.266 & 0.490 \\
\hline Public & 18.9 & 39.5 & 0.56 & 1.47 & 0.028 & 0.086 \\
\hline Secondary & 34.2 & 45.2 & 1.20 & 1.78 & 0.069 & 0.107 \\
\hline Commerce & 37.6 & 54.7 & 1.46 & 2.58 & 0.092 & 0.176 \\
\hline Transportation & 38.1 & 40.0 & 1.28 & 1.57 & 0.074 & 0.079 \\
\hline Others & 31.0 & 56.9 & 1.08 & 2.49 & 0.066 & 0.161 \\
\hline \multicolumn{7}{|l|}{ Education level } \\
\hline None & 60.0 & 72.6 & 2.83 & 4.51 & 0.201 & 0.409 \\
\hline Primary & 47.2 & 61.4 & 2.00 & 3.48 & 0.133 & 0.281 \\
\hline At least secondary & 20.5 & 41.0 & 0.71 & 1.72 & 0.045 & 0.109 \\
\hline \multicolumn{7}{|l|}{ Farm } \\
\hline None & 51.3 & 74.1 & 2.29 & 4.63 & 0.157 & 0.419 \\
\hline Exporting & 49.5 & 46.0 & 2.26 & 2.29 & 0.159 & 0.174 \\
\hline Food crop & 49.7 & 48.1 & 2.33 & 2.19 & 0.169 & 0.150 \\
\hline \multicolumn{7}{|l|}{ Non-farm enterprise } \\
\hline Yes & 47.3 & 62.9 & 1.99 & 3.34 & 0.133 & 0.260 \\
\hline No & 52.7 & 63.0 & 2.52 & 3.85 & 0.181 & 0.349 \\
\hline \multicolumn{7}{|l|}{ Region } \\
\hline Abidjan & 12.7 & 38.7 & 0.27 & 1.71 & 0.01 & 0.112 \\
\hline Other cities & 44.6 & 58.7 & 1.73 & 2.73 & 0.10 & 0.189 \\
\hline East Forest & 62.2 & 72.2 & 2.66 & 4.01 & 0.17 & 0.338 \\
\hline West Forest & 70.3 & 76.2 & 3.77 & 5.47 & 0.29 & 0.531 \\
\hline Savannah & 77.7 & 80.0 & 4.26 & 5.56 & 0.33 & 0.539 \\
\hline \multicolumn{7}{|l|}{ Ethnic group } \\
\hline Akan & 42.5 & 62.4 & 1.60 & 3.31 & 0.09 & 0.266 \\
\hline Krou or Voltaic & 59.0 & 65.3 & 2.99 & 4.10 & 0.22 & 0.372 \\
\hline Mande & 56.6 & 59.4 & 2.85 & 3.59 & 0.22 & 0.315 \\
\hline Non Ivoirian & 46.7 & 63.5 & 2.02 & 3.56 & 0.13 & 0.296 \\
\hline Aggregate poverty & 50.4 & 62.9 & 2.29 & 3.65 & 0.16 & 0.313 \\
\hline
\end{tabular}


Table 3

Niger: Contribution to poverty of different groups before and after the devaluation (\%)

\begin{tabular}{|c|c|c|c|c|c|c|}
\hline & \multicolumn{6}{|c|}{ Poverty line $z=$ CFAF 150000} \\
\hline & \multicolumn{2}{|c|}{ Head count $P_{0}$} & \multicolumn{2}{|c|}{ Poverty gap $P_{1}$} & \multicolumn{2}{|c|}{ FGT $P_{2}$} \\
\hline & 1994 & 1995 & 1994 & 1995 & 1994 & 1995 \\
\hline \multicolumn{7}{|l|}{ Socio-economic category } \\
\hline Idle & 61.9 & 83.3 & 5.89 & 8.81 & 0.92 & 1.48 \\
\hline Management and professional & 12.4 & 32.6 & 0.42 & 1.47 & 0.03 & 0.13 \\
\hline Administrative staff & 23.4 & 52.7 & 1.96 & 2.30 & 0.33 & 0.16 \\
\hline Service staff & 40.3 & 73.1 & 2.71 & 5.61 & 0.36 & 0.64 \\
\hline Unskilled workers & 56.1 & 76.3 & 3.37 & 4.74 & 0.34 & 0.46 \\
\hline Traders & 50.3 & 78.3 & 3.26 & 6.25 & 0.37 & 0.73 \\
\hline Craftsmen & 47.3 & 77.0 & 3.52 & 7.12 & 0.47 & 0.97 \\
\hline Marabouts and other religions & 63.2 & 84.8 & 5.43 & 7.94 & 0.83 & 1.15 \\
\hline Farmers & 84.7 & 96.2 & 8.02 & 13.5 & 1.14 & 2.47 \\
\hline \multicolumn{7}{|l|}{ Status in occupation } \\
\hline Unknown & 63.0 & 92.6 & 6.06 & 12.8 & 0.96 & 2.38 \\
\hline Entrepreneur & 45.3 & 54.5 & 2.80 & 3.96 & 0.32 & 0.50 \\
\hline Self-employed & 70.8 & 88.0 & 6.22 & 9.96 & 0.87 & 1.58 \\
\hline Public sector employees & 26.4 & 55.6 & 1.22 & 3.13 & 0.10 & 0.28 \\
\hline Private sector employees & 84.1 & 63.0 & 7.31 & 4.40 & 0.82 & 0.53 \\
\hline Family helpers & 50.0 & 91.4 & 4.20 & 11.7 & 0.75 & 2.13 \\
\hline Others & 56.6 & 78.6 & 3.16 & 6.94 & 0.23 & 0.99 \\
\hline \multicolumn{7}{|l|}{ Education level } \\
\hline None & 70.8 & 91.0 & 6.22 & 11.1 & 0.87 & 1.89 \\
\hline Primary & 43.0 & 79.6 & 2.51 & 6.82 & 0.26 & 0.96 \\
\hline At least secondary & 18.2 & 46.8 & 0.90 & 2.68 & 0.09 & 0.26 \\
\hline \multicolumn{7}{|l|}{ Farming } \\
\hline None & 55.9 & 74.7 & 4.64 & 6.34 & 0.66 & 0.84 \\
\hline Yes & 77.8 & 95.2 & 6.76 & 13.0 & 0.89 & 2.37 \\
\hline \multicolumn{7}{|l|}{ Non-farm enterprise } \\
\hline None & 57.1 & 82.2 & 7.10 & 10.1 & 0.77 & 1.82 \\
\hline Yes & 63.9 & 87.4 & 5.17 & 9.60 & 0.68 & 1.50 \\
\hline \multicolumn{7}{|l|}{ Region } \\
\hline Urban & 46.7 & 77.8 & 2.80 & 6.66 & 0.29 & 0.84 \\
\hline Rural & 84.2 & 96.4 & 8.90 & 14.4 & 1.39 & 2.79 \\
\hline Aggregate poverty & 61.3 & 85.3 & 5.17 & 9.82 & 0.71 & 1.63 \\
\hline
\end{tabular}

The criterion of education provides also some interesting information. The incidence of poverty increased the most, in relative terms, among the persons with at least a secondary education level, in relative terms. Here again, this criterion points at the formal sector, as few educated persons work in the informal sector. People without any education were less affected by the deterioration, in terms of headcount. However, the use of the distribution-sensitive measures shows that all were affected. The next 
partition shows that people involved in farming were somehow protected from the increase in poverty. This is true for the headcount index, and for the poverty gap measure, as far as the food crop growers are concerned. But it is not true for the last measure. By contrast, the fact of owning a non-farm enterprise has no discriminating power.

The next partition is especially interesting. Here, the geographic criterion is used, decomposing the population first according to the urban/rural distinction, and then among the rural people, according to the most relevant regional division: Savannah, in the north, and east and west forest zones, for the south. While the rural people have not been shielded from the increase in poverty, whichever measure is used, it is clear that urbanites suffered the strongest deterioration. Abidjan, in particular saw its situation deteriorate massively. The West Forest and the Savannah zones got a much softer impact. The East Forest zone, the traditional Akan area, where cocoa and coffee have been grown since the beginning, saw also a non negligible increase in poverty. Even among the relatively protected groups, in terms of headcount, the data show that the deterioration is worse, the more distribution-sensitive is the measure used.

The last partition also gives some interesting clues. It is the traditionally dominant group, the Akan who paid the largest price, in terms of deteriorating poverty. Incidence is then even larger than among the Mande, a northern group from the Savannah. In fact, the Akan have been politically dominant between independence and the 1999 military coup. They were the most numerous in the public sector and other segments of the formal sector (Azam and Morrisson 1994).

Therefore, the data are consistent with a story where the formal sector workers, and in particular those from the public sector, have seen somehow their poverty situation deteriorate, and have brought down with them the living standards of other urbanites, mainly in the commerce sector, but in other sectors as well. Then, some spill over from the worsened urban situation to the rural one, somehow in the Harris-Todaro spirit, probably followed, as the rural-urban migration probably slowed down, or even reversed itself in some cases (Harris and Todaro 1970).

Regarding the dates at which the household surveys have been performed, the data for Niger as not as suitable as the Ivoirian ones, as the they took place in 1994 and 1995, so that the post-devaluation era has been observed en route. On the other hand, their sample size is more balanced, as the 1994 survey provides a sample of 3,823 households, and the 1995 one 4,067. Because the post-devaluation adjustment was already in the process when the first survey was done, the inflation rate between the two rounds is smaller, namely 10.9 per cent. This might be an underestimation of the true average increase in consumer prices that affected the sample households, because it refers to the change in prices between the two dates, at the end of the year. This is at variance with the Côte d'Ivoire case, where we might suspect an over-estimation. Nevertheless, the two before-after comparisons provide roughly the same picture. In fact, Table 3 suggests that the increase in poverty in the wake of the devaluation is larger and deeper in Niger that in Côte d'Ivoire. Only the private sector employees, whichever the poverty measures used, and the administrative staff for $P_{2}$, seem to have seen their poverty situation improve. All the other socio-economic categories have seen poverty go up among their members, somehow like in Côte d'Ivoire. In relative terms again, it is in the urban sector that the blow hit the hardest. But here, even the farmers saw their poverty situation worsen. 
The next section presents a simple model that helps to think about the way in which this type of real wage cut works through the various segments of the labour market, to affect the earnings of the workers in the informal sector.

\section{A model of informal sector wage dynamics in the shadow of the devaluation}

In order to go further in the analysis, we need to take into account the type of labour market rigidity that can be observed in many developing countries: the wages in the formal sector are higher than in the other sectors, and do not respond flexibly to the fluctuations of the demand for- and supply of labour. The first authors to have drawn some consequences of this observation were Harris and Todaro (1970). In their model, the workers are facing a trade off between working in the rural sector, where full employment prevails, or in the urban sector, where there is some unemployment, on the one hand, and a formal sector with a rigid wage, on the other hand. The migration equilibrium is found where the mathematical expectation of the urban wage, which is equal to the formal sector wage multiplied by the probability of finding a job there, is equal to the rural wage. This model has been criticized by Jamal and Weeks (1993) as giving a distorted picture of the working of the typical African labour market, putting too much emphasis on the rural-urban wage gap, related to the so-called urban bias (Lipton 1977), while wage inequalities within the urban sector are probably more significant.

The model presented here does not fall under this criticism, and it takes on board the typical stratification of African labour markets. It used to be widely said, before the devaluation, that formal sector workers were supporting on average more than forty people with their earnings. Nowadays, people are citing more generally the number of twenty. Most of the time, the relatively well off formal sector workers provide jobs to members of their social network (extended family, kin group, village of origin, etc.), either at home as domestic helpers, or in some businesses that they are running in the informal sector (taxis, small shops, garment production, food processing, etc.). Moreover, these businesses provide an outlet for their savings, which they rarely deposit with formal financial institutions. The banking crisis of the late 1980s suggests that their distrust of the banking sector was based on rational expectations. In fact, in the words of Aryeetey and Udry (1997): 'the conclusion of virtually all studies of informal finance in both rural and urban Africa is that a substantial majority of lending occurs among friends, family and neighbours'. Azam et al. (2001) support this view, using a sample of manufacturing firms in Côte d'Ivoire. They show that this is the cheapest way of getting funding for the firms who have access to this type of credit, while the formal banking sector caters for those who have no access to the informal sector, or who want to finance very large investment projects. Conversely, African savers invest most of their money in informal sector businesses, or even in small and medium sized firms of the formal sector.

The formal sector workers are supposed to earn a wage $w^{F}$, and to run simultaneously a small business in the informal sector. The production function for the latter is denoted $f(k, \ell)$, and is supposed to be well-behaved, with constant returns to scale, and positive and decreasing marginal returns. Assume that the informal sector labour market is competitive, with a ruling wage $w^{I}$. The representative formal sector worker, assumed infinitely lived, seeks to maximize: 


$$
\int_{0}^{\infty} u(c) e^{-r t} d t
$$

subject to the following budget constraint:

$$
d k / d t=w^{F}+f(k, \ell)-w^{I} \ell-c .
$$

Applying Pontryagin's Maximum Principle, one derives easily the following three optimality conditions, where subscripts represent again partial derivatives:

$$
\begin{aligned}
& f_{\ell}(k, \ell)=w^{I}, \\
& f_{k}(k, \ell)=r+\varepsilon d \log c / d t,
\end{aligned}
$$

and

$$
\lim _{t \rightarrow \infty} u^{\prime}(c) k e^{-r t}=0
$$

Condition (5) simply says that the informal sector firm will hire labour up to the point where its marginal productivity is equal to the ruling wage. Condition (6) is the standard Keynes-Ramsey formula, equating the marginal product of capital in the informal sector, which measures the real rate of interest for the representative saver analysed here, to the subjective rate of interest. Here, $\varepsilon=\frac{-c u^{\prime \prime}(c)}{u^{\prime}(c)}$ is the relative degree of risk aversion, more appropriately called here aversion to change. Lastly, (7) is the transversality condition.

Given the condition on the marginal productivity of labour, and assuming a given supply of labour $\tilde{\ell}$, equilibrium on the informal sector labour market allows to define the profit function as:

$$
\pi(k, \tilde{\ell})=f(k, \tilde{\ell})-\tilde{\ell} f_{\ell}(k, \tilde{\ell}) .
$$

Moreover, after substituting the labour supply in (5), one derives easily that the equilibrium wage rate in the informal sector is an increasing function of the capital stock, by differentiating it. This yields:

$$
\frac{\partial w^{I}}{\partial k}=f_{\ell k}(k, \tilde{\ell})>0 .
$$

Therefore, there is a one-to-one correspondence between the dynamics of the informal sector wage rate and that of the capital stock invested in this sector. It is more convenient to focus now on the latter.

The dynamics of the model is governed by the following pair of differential equations: 


$$
\frac{d c}{d t}=\frac{c}{\varepsilon}\left(f_{k}(k, \tilde{\ell})-r\right)
$$

and:

$$
\frac{d k}{d t}=w^{F}+\pi(k, \tilde{\ell})-c
$$

Notice that the function $\pi(k, \tilde{\ell})$ is most likely to be increasing and concave in $k$. It is so for the CES production function, for example. However, this requires some conditions on second and third derivatives, that need not retain us here.

For any given value of $w^{F}$, one can draw the phase diagram of Figure 4 . The vertical line is the locus $d c / d t=0$, where the marginal product of capital in the informal sector is equal to the rate of time preference of the representative saver. Consumption is moving upwards for all points located on the left-hand side of this vertical line, where the real rate of interest is higher than the rate of time preference, and it is moving downwards on the right-hand side. The upward sloping concave curve is the locus $d k / d t=0$. Above it, consumption is too high, and the capital stock falls. Below it, the agent is saving, and capital is moving upwards. The arrows drawn in the different zones of the phase space represent this dynamics.

Figure 4

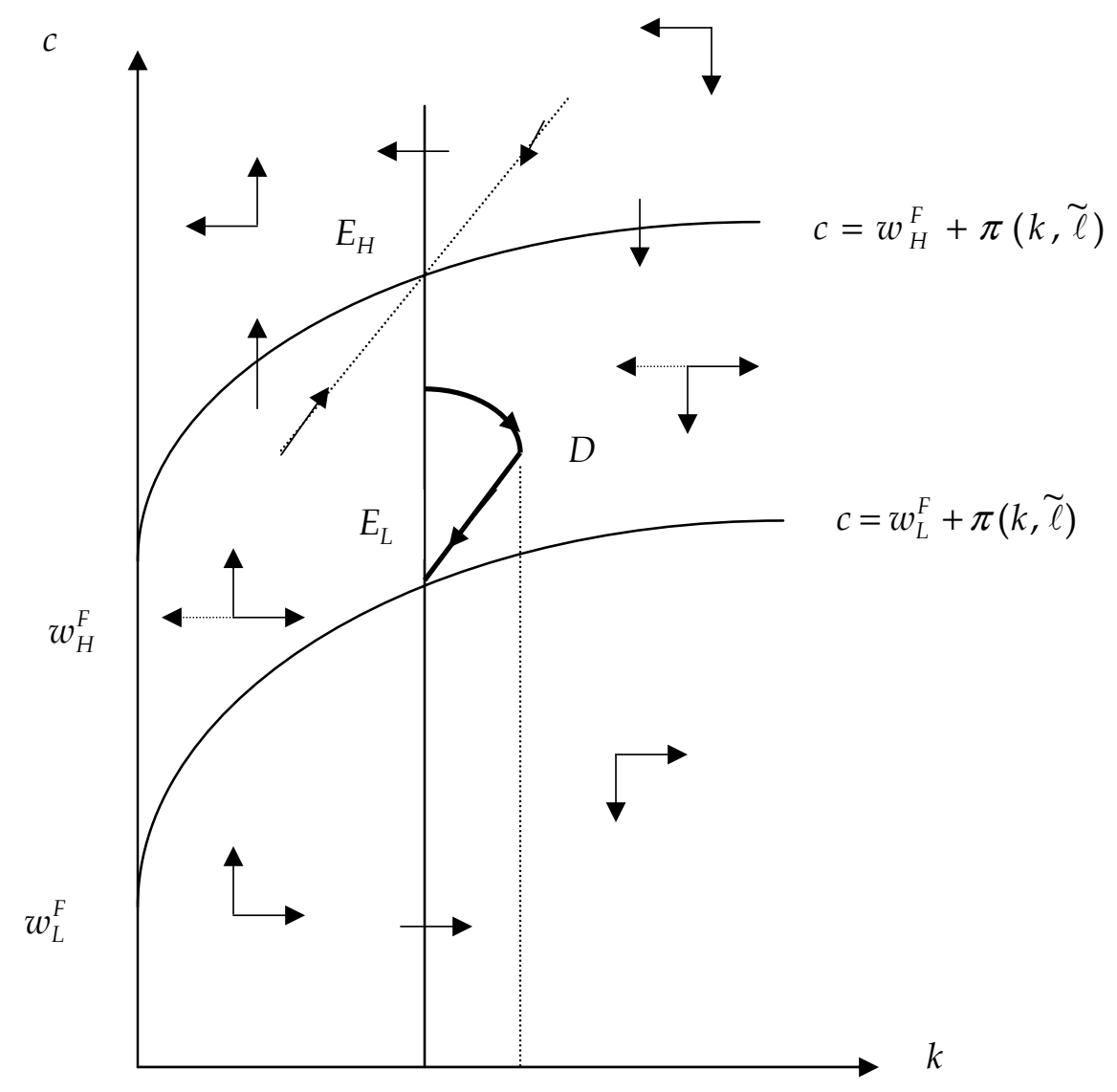


If $w^{F}$ was constant, then the agent would select the saddle path of the phase diagram of Figure 4, drawn with a dotted line. However, we are interested here in the case where the agent is predicting that $w^{F}$ will fall in the future, either because of a devaluation, or because of any other adjustment policy. Assume that the representative agent has reached initially the steady state corresponding to $w^{F}=w_{H}^{F}$, labelled $E_{H}$ on Figure 4. Now, the agent understands at date zero, for whatever reason, that their wage will be cut at a future date $T$. How will one respond? In order to deal with this question, assume that $w^{F}$ follows the following path:

$$
w^{F}=w_{H}^{F}, \text { for } t<T,
$$

and

$$
w^{F}=w_{L}^{F}<w_{H}^{F}, \text { for } t \geq T
$$

In this case, the locus $d k / d t=0$ shifts downwards exactly at date $T$, and stays there for ever after. As usual with this type of models, we must work backward to find the right trajectory. It is clear that the agent must choose a consumption path which lies on the saddle path after date $T$, aiming at the steady state $E_{L}$, for the usual reasons. The arbitrage condition (6) rules out any discontinuity in the trajectory of $c$ at any future period. Therefore, one will cut immediately their consumption at date zero, in order to follow a trajectory heading to the south-east of the phase space, and reaching the saddle path at exactly date $T$. Such a trajectory is represented in Figure 4 by the curvilinear downward sloping curve, heading to the south-east. This is a divergent trajectory relative to the steady state labelled $E_{H}$, according to the dynamics prevailing prior to $T$. It reaches the saddle path heading to $E_{L}$ at point $D$.

In other words, in this dynamic model, the prospect of a future cut in one's formal sector wage induces the representative formal sector worker to start saving as soon as they form this prediction, for the sake of consumption smoothing. One invests these increased savings in their informal sector business, with a positive impact on the wages prevailing there, and will gradually deplete this extra capital when the wage cut occurs, that is, in this case, in the wake of the devaluation, in order to slow down the fall in consumption.

The capital stock thus increases prior to the devaluation, as soon as the formal sector worker starts predicting the future wage cut, and decreases gradually after its occurrence. We know from (9) that the informal sector wage rate will follow suit, going up in the pre-devaluation phase, starting when the prediction of the future wage cut arises, and going down in the post devaluation phase. Hence, this analysis predicts that the informal sector thrives in the shadow of the devaluation, leading to the so-called 'informalization' of the economy, but begins to suffer when the light resumes.

Casual observation suggests that the process of informalization just described occurred in most CFA zone countries, as soon as the structural adjustment programmes started. In the case of Niger, Azam et al. (1993) have described the expansion of the informal sector in the city of Niamey in the wake of the adoption of a structural adjustment programme in 1982. This was made possible thanks to a pair of surveys of the informal 
sector performed by the local Statistical Office with the support of the ILO, in 1981, just before the change in policy, and in 1988. A point that was regarded by many as contentious at the time was that the wages in the informal sector firms were going up by about 20 per cent between these two dates, in real terms. The number of established informal sector firm, that is, disregarding street vendors, door-to-door traders, etc., in Niamey increased by 125 per cent over this period, while the population increased by about 33 per cent. The average number of employees per firm increased from 1 to 1.4. The local donor community was puzzled. The model just presented offers a neat interpretation of this observation: as formal sector workers were perceiving their position in the formal sector under threat, especially in various state-owned enterprises, they increased their saving and investment in informal sector firm. This had a positive impact on wages there.

I am not aware of similar data for Côte d'Ivoire, where only indirect evidence is available. The informalization process is nevertheless highly plausible there as well, in view of the existing evidence. According to Grootaert (1996), informal sector employment grew steadily between 1980, at the beginning of the adjustment process, and 1992 (Grootaert 1996: 81). It increased over this 12 year period by 153 per cent, while it only increased in the whole country by 52 per cent. Moreover, there is some evidence of rural-urban migration over this period, as employment in agriculture only grew by 38 per cent. This suggests that earnings in the informal sector became more attractive than in agriculture over that period. In the meantime, employment in the 'modern sector' fell by 14 per cent, reflecting the effects of the two waves of adjustment programmes (Azam and Morrisson 1994). Another indirect look at this process can be derived from the CILSS (Côte d'Ivoire Living Standard Survey), which took place in four rounds in 1985 through 1988. It shows that the incidence of extreme poverty fell in the informal sector, for both employees and self-employed, between 1985 and 1987 (Grootaert 1996: 81). Then, it increased abruptly in 1988, in the wake of the terms of trade crash that occurred at the end of 1987. Nevertheless, the self-employed in this sector remained better off in 1988 than in 1985, according to this criterion.

\section{Conclusion}

This paper has analysed the effects of the 1994 devaluation of the CFAF on growth and poverty in the WAEMU, with a medium run horizon. Examination of the data has first shown that the crucial channel of impact is the fall in the real wages of the formal sector workers, which had not been achieved by any other means in most CFA zone countries. Labour markets are known to be segmented in African economies, between the rural and the urban sector, on the one hand, and within the latter, between the formal and the informal sector, on the other hand. This is what the classic Harris-Todaro model is meant to capture. I did not follow this path here, and modelled instead the stratification of the labour market between formal and informal sectors. The crucial link is through the fact that formal sector workers, who are much more affluent than the other workers, in most countries of the CFA zone, are running businesses in the informal sector. They invest their savings in small firms, where they generally employ people from their social network. Then, it is the increase in saving induced by the prospect of a future wage cut, due to an expected devaluation or to other reasons, that drives the predicted dynamics of the model. For the sake of smoothing consumption, formal sector workers begin to increase their saving in anticipation of the cut in their purchasing power, and invest 
more in their informal sector firms. This entails an increase in informal sector wages, in the pre-devaluation period, as capital intensity increases in equilibrium. However, when the cut comes, like it did after the 1994 devaluation, then the savers are running down gradually their assets, and informal sector wages go down. It is thus a medium-run model of a stratified labour market, as it takes into account capital accumulation and decumulation, while it does not take on board longer term processes like technical progress and the accumulation of human capital. In particular, it does not take into account the improvement in public finance that resulted from the policy change, and which will in due course improve the supply of health and education services.

This provides a rationale for an observation which seems puzzling at first, namely that poverty increased a lot in the wake of the 1994 devaluation in Côte d'Ivoire and Niger, and most probably in other CFA zone countries. The designers of this measure were expecting a response in the other direction, hoping that the depreciation would mainly entail an improvement in agricultural prices, boosting the incomes of the rural poor. The results found by looking at the change in various standard measures of poverty before and after the devaluation in Côte d'Ivoire and Niger show in fact a marked deepening of poverty, despite the resumption of GDP growth. Only the people somehow related to agriculture got some relative protection from the cut in living standards, in Côte d'Ivoire. Preliminary results using the 1998 survey by Kouadio et al. (2000) and by Grimm (2001), while using different approaches, confirm that urban poverty increased in Côte d'Ivoire in the wake of the devaluation, while they show that some recovery took place in the rural sector, especially among food crop farmers and export crop farmers from the West Forest area. This was in part the result of the improvement in world prices for export crops. While unexpected at the time of the decision, this type of de-linking of growth and poverty is not unheard of. Deaton (2001) concludes: 'Thus economic growth, as measured, has at best a weak relationship with poverty, as measured' (Deaton 2001: 125). The story presented here suggests that the standard favourable impact of a devaluation, mediated by the recovery of economic growth, should only be expected from an unexpected devaluation.

These results are not perfectly satisfactory, insofar as the data are not ideally suited for this exercise. In both countries, there are problems with the consumer price index, while the 1995 survey in Côte d'Ivoire has a small sample, and the 1994 survey in Niger has been performed while the devaluation was already done. The convergent results of these two before-after comparisons, for two very different countries, at a drastically different level of income per capita, suggest either of two conclusions: (i) the labour earnings of the poor have really fallen behind the devaluation-induced price rises, entailing a fall in their real incomes, or (ii) we have a more fundamental methodological problem, namely that consumption expenditures are in this case a misleading indicator of incomes, because despite some increase in labour earnings, households have decided to reduce consumption in order to restore the level of their assets. After all, the real balance effect is one of the standard mechanisms whereby a devaluation is supposed to help cutting absorption, in standard open-economy macroeconomics. Only a detailed study of the evolution of earnings in different segments of the labour market, which falls outside the scope of the present paper, can hope to shed some light on this issue. Nevertheless, it seems unlikely that the poor held a lot of nominal assets whose real value was cut by the devaluation, beside the wages of their relatives working in the formal sector. 


\section{References}

Alesina, A. and A. Drazen (1991). 'Why Are Stabilizations Delayed?'. American Economic Review, 81 (5): 1170-88.

Aryeetey, E. and C. Udry (1997). 'The Characteristics of Informal Financial Markets in Sub-Saharan Africa'. Journal of African Economies 6 (1): 161-203.

Azam, J.-P. (1991). 'Niger and the Naira: Some Monetary Consequences of CrossBorder Trade with Nigeria', in A. Chhibber and S. Fischer (eds), Economic Reform in Sub-Saharan Africa. Washington, DC: World Bank, pp. 66-75.

Azam, J.-P. (1994). 'The Uncertain Distributional Impact of Structural Adjustment in Sub-Saharan Africa', in R. van der Hoeven and F. van der Kraaij (eds), Structural Adjustment and Beyond in Sub-Saharan Africa: Research and Policy Issues. London: DGIS, James Currey and Heinemann, pp. 100-113.

Azam, J.-P. (1995). 'L'Etat auto-géré en Afrique'. Revue d'économie du développement, 1995 (4): 1-19,: décembre.

Azam, J.-P. (1997). 'Public Debt and the Exchange Rate in the CFA Franc Zone'. Journal of African Economies, 6 (1): 54-84.

Azam, J.-P., B. Biais, M. Dia and C. Maurel (2001). 'Informal and Formal Credit Markets and Credit Rationing in Côte d'Ivoire'. Oxford Review of Economic Policy, 17 (4): 520-34.

Azam, J.-P., C. Bonjean, G. Chambas and J. Mathonnat (1993). Le Niger. La pauvreté en période d'ajustement. Paris: L'Harmattan.

Azam, J.-P. and C. Morrisson (1994). The Political Feasibility of Adjustment in Côte d'Ivoire and Morocco. Paris: Development Centre Studies, OECD.

Azam, J.-P. and W. Wane (2001). The 1994 Devaluation and Poverty in the WAEMU. Unpublished. Washington, DC: World Bank.

Casella, A. and B. Eichengreen (1996). 'Can Foreign Aid Accelerate Stabilisation?'. Economic Journal, 106 (436): 605-19.

Deaton, A. (2001): 'Counting the World's Poor: Problems and Possible Solutions'. World Bank Research Observer, 16 (2), 125-147.

Demery, L. and L. Squire (1996). 'Macro economic Adjustment and Poverty in Africa: An Emerging Picture'. World Bank Research Observer, 11: 39-59.

Devarajan, S. and D. Rodrik (1992). 'Do the Benefits of Fixed Exchange Rates Outweigh their Costs: The CFA zone in Africa', in I. Goldin and L. A. Winters (eds), Open Economies: Structural Adjustment and Agriculture. Cambridge: Cambridge University Press, pp. 66-92.

Fernandez, R. and D. Rodrik (1991). 'Resistance to Reform: Status Quo Bias in the Presence of Individual-Specific Uncertainty'. American Economic Review, 81 (5): 1146-55.

Foster, G., J. Greer and E. Thorbecke (1984). 'A Class of Decomposable Poverty Measures'. Econometrica, 52: 761-66. 
Grimm, M. (2001). 'Macroeconomic Adjustment, Sociodemographic Change, and the Evolution of Income Distribution in Côte d'Ivoire'. Unpublished. Helsinki: UNUWIDER.

Grootaert, C. (1996). Analyzing Poverty and Policy Reform, with contributions from Lionel Demery and Ravi Kanbur. Aldershot: Avebury.

Grootaert, C. and R. Kanbur (1995). 'The Lucky Few Amidst Economic Decline: Distributional Change in Côte d'Ivoire as Seen Through Panel Data Sets, 1985-88'. Journal of Development Studies, 31 (4): 603-19.

Harris, J. R. and M. P. Todaro (1970). 'Migration, Unemployment, and Development: A Two-Sector Analysis'. American Economic Review, 60: 126-142.

IMF (2000a). Côte d'Ivoire. Selected Issues and Statistical Appendix (processed). Washington, DC: IMF.

IMF (2000b). Senegal. Recent Economic Developments (processed). Washington, DC: IMF.

Jamal, V. and J. Weeks (1993). Africa Misunderstood or Whatever Happened to the Rural-Urban Gap? London: Macmillan.

Kouadio, A. K., M. N'Zi, D. N'Guessan and I. Ouattara (2000). Ajustement monétaire et pauvreté alimentaire en Côte d'Ivoire, rapport d'étape révisé, CREA-AERC, processed. Université d'Abidjan - Cocody.

Lipton, M. (1977). Why Poor People Stay Poor: A Study of Urban Bias in World Development. London: Temple Smith.

Ouattara, I. (1997). Profil de pauvreté en Côte d'Ivoire 1993 et 1995, résultats définitifs. Abidjan: Institut national de la statistique.

Rama, M. (2000). 'Wage Misalignment in CFA Countries: Were Labour Market Policies to Blame?'. Journal of African Economies, 9 (4): 475-511.

Van de Walle, N. (1991). 'The Decline of the Franc Zone: Monetary Politics in Francophone Africa'. African Affairs, 90: 383-405.

World Bank (1997). African Development Indicators (diskette). Washington, DC: World Bank. 